\title{
APPENDECTOMY, COMPARATIVE STUDY BETWEEN A PUBLIC AND A PRIVATE HOSPITAL
}

Júlio C. U. Coelho ${ }^{*}$, Fabiana Marques Fernandes ${ }^{2}$, Luís Gustavo G. Cortiano ${ }^{3}$, Gustavo Munhoz de Oliveira Leme ${ }^{4}$, José Alfredo Sadowski ${ }^{5}$, Christian Luiz Artner ${ }^{6}$ Study conducted at Serviço de Cirurgia do Aparelho Digestivo do Hospital de Clínicas da Universidade Federal do Paraná e do Hospital Nossa Senhora das Graças de Curitiba, Curitiba, PR

\author{
*Correspondence: \\ Rua Bento Viana, 1140 - \\ Ap. 2202 \\ Curitiba - PR \\ CEP: 80240-110 \\ Fone/Fax: (+ 55 41) \\ 3322-3789 \\ coelhojcu@yahoo.com.br
}

\begin{abstract}
SUMMARY
OвJective. The aim of this study is to compare data of patients submitted to appendectomy for acute appendicitis at a public hospital and at a private hospital.

Methods. A total of 200 medical records of patients submitted to appendectomy for acute appendicitis at a public hospital $(n=100)$ and at a private hospital $(n=100)$, was reviewed retrospectively.

Results. Mean age and gender distribution were similar for patients of both hospitals. More patients had been previously evaluated by other physicians in the group of the public hospital $(n=85)$ than of the private hospital $(n=13)(p<0.0001)$. Ultrasonography was performed more frequently on patients of the public hospital $(n=56)$ than of the private hospital $(n=30)(p=0.0002)$. Length of hospital stay was longer at the public hospital ( $3.5 \pm 2.8$ days) than at the private hospital ( $2.5 \pm 1.7$ days) $(p=0.0024)$. Postoperative complications were more frequent at the public hospital $(n=36)$ than at the private hospital $(n=20)(p<0.0117)$. Time to resume routine activities was longer for the public hospital (33.2 \pm 8.3 days) than for the private hospital $(16.4 \pm 5.2$ days $)(p<0.0001)$. Multivariate logistic-regression analysis showed that the estimated probability of complicated appendicitis increased with the time interval between onset of symptoms and appendectomy $(p<0.001)$. Independent risk factor associated with complicated appendicitis was the time interval between onset of symptoms and appendectomy (odds ratio $41.65,95 \% \mathrm{Cl}$ \{confidence interval\} 2.90-597.49, $\mathrm{p}<0.0001$ ) at the public hospital. There was no independent risk factor associated with complicated appendicitis at the private hospital.

ConcLusion. There are important differences between public and private hospitals in the diagnosis and outcomes of patients with acute appendicitis submitted to appendectomy.
\end{abstract}

KEY WORDS: Socioeconomic factors. Appendicitis. Appendectomy. Health insurance. Postoperative complications.

\section{INTRODUCTION}

Acute appendicitis is the most common cause of acute abdominal pain and appendectomy is the most frequently performed emergency surgery in the world ${ }^{1,2}$. Although acute appendicitis mortality is low, morbidity remains high ${ }^{3,4}$. The complication rate is related mainly with appendiceal perforation ${ }^{3}$. and increases 10 times after appendiceal perforation ${ }^{2,5,6}$. Diagnosis of acute appendicitis is established primarily on patient's history and physical examination supported by laboratory and imaging exams $^{7-10}$. Delay in the diagnosis and treatment is by far the main cause of appendiceal perforation ${ }^{11-16}$.
Some international studies have demonstrated that medical evaluation, appendiceal perforation and postoperative complication of patients with acute appendicitis who have undergone appendectomy are related with type of hospital assistance, physician's specialty, geographic area and patients' socioeconomic status ${ }^{1,17-19}$. Emergency department consultation for evaluation of patients with acute appendicitis may be related to the socioeconomic status of the patient ${ }^{18}$. In the USA, waiting time for consultation in the emergency department to evaluate patients with acute appendicitis is longer for those in a lower socioeconomic bracket ${ }^{18}$. Furthermore, in some countries,

1. Pós-Doutorado - Professor Titular e Chefe do Serviço de Cirurgia do Aparelho Digestivo e Transplante Hepático do Hospital de Clínica da Universidade Federal do Paraná, Curitiba, PR

2. Médica residente do Hospital Nossa Senhora das Graças de Curitiba, Curitiba, PR

3. Médico residente do Hospital de Clínicas da Universidade Federal do Paraná, Curitiba, PR

4. Acadêmico de Medicina do Setor de Ciências da Saúde da Universidade Federal do Paraná, Curitiba, PR

5. Médico Residente do Hospital de Clínicas da Universidade Federal do Paraná

6. Médico Residente do Hospital Nossa Senhora das Graças de Curitiba, Curitiba, PR 
hospital stay is longer and also more expensive preoperative imaging exams are usually performed in public hospitals than in private hospitals ${ }^{19}$. There is no data in Brazil comparing diagnosis and outcomes of patients submitted to appendectomy for acute appendicitis at a public hospital and a private hospital. Our hypothesis is that at a private hospital, patients with acute appendicitis are submitted to clinical evaluation and appendectomy in a shorter period of time and possibly with a lesser postoperative complication rate than patients at a public hospital. Our objective is to compare preoperative, peri-operative, and postoperative data of patients submitted to appendectomy for acute appendicitis at a public hospital and at a private hospital.

\section{Methods}

Medical records of the first 100 consecutive patients subjmitted to appendectomy for acute appendicitis beginning on January 1, 2007 at the Hospital de Clinicas of the Federal University of Parana and the Hospital Nossa Senhora das Graças were retrospectively reviewed. Study period extended to March 14, 2009 at the Hospital de Clinicas and December19, 2008 at the Hospital Nossa Senhora das Graças. The Hospital de Clinicas is a teaching (University) public hospital and the Hospital Nossa Senhora das Graças is a private hospital. All patients admitted to the public hospital had universal government health insurance and all admitted to the private hospital had private insurance or were private patients without health insurance. Surgical coordination and staff of both hospitals comprised the same group of certified gastrointestinal surgeons. Staff members had 9 to 33 years of surgical practice and all had at least three years of surgical residency training and are certified by the Brazilian College of Surgeons and Brazilian College of Gastrointestinal Surgery. Both hospitals have surgical residency programs in general surgery and gastrointestinal surgery certified by the Brazilian Secretary of Education.

The study was approved by the Ethics Committee of the two hospitals. The following data were obtained and analyzed: age, gender, clinical and diagnostic test findings, previous evaluation by other physicians, type of surgery (ie, laparoscopic or open), operative findings, postoperative complications, length of hospital stay, hospital readmission and time to resume routine activities (work and or study). Patients with false-positive diagnosis of acute appendicitis were excluded from the study.

Complicated appendicitis was defined by presence of gangrene, perforation, abscess, or peritonitis. Cefoxitin was given routinely at anesthesia induction to all patients of both hospitals. This was converted into an antibiotic combination of metronidazole and ceftriaxone and continued for at least five days if appendicitis was complicated. Gastric tube or urinary catheter was not used routinely.

Patients returned for ambulatory follow-up at the $7^{\text {th }}$ day and one and three months after surgery. Follow-up was extended as required by presence of complications.

Values were expressed as mean \pm SD (standard deviation). Statistical analysis was performed using the Excel Microsoft software and the Statistica version 9 software (StatSoft Inc., Tulsa, OK, USA). Student's t-test was employed to determine the difference between means and the chi-square test to assess the difference between expected frequencies and those observed in the two groups. Multivariate logistic regression analyses were performed to identify risk factors associated with complicated appendicitis. Kaplan-Meier analysis was used to determine the relationship between the cumulative probability of complicated appendicitis and the time interval between onset of symptoms and appendectomy. Results were considered statistically significant when $p \leq 0.05$.

\section{RESULTS}

Mean age and gender distribution of patients were similar for groups of both hospitals (Table 1 ). All patients admitted to the private hospital were private or had private health insurance allowing them to choose the physician or the hospital.. These patients usually had college or university education and belonged to the middle or upper social class. Patients admitted to the public hospital had government health insurance and usually were first evaluated in an outpatient clinic by a general physician and referred to the hospital when diagnosis of appendicitis was established or suspected. These patients usually had no university education and belonged to the lower or middle social class. There was no difference in the number of patients with false-positive diagnosis of acute appendicitis between the public hospital $(n=13)$ and the private hospital $(n=18)(p=0.3692)$.

A larger number of patients was previously evaluated by another physician in the group operated upon at the public hospital $(n=85)$ than at the private hospital $(n=13)(p<0.0001)$. Clinical

\begin{tabular}{|c|c|c|c|}
\hline Preoperative Data & $\begin{array}{l}\text { Public } \\
\text { Hospital }\end{array}$ & $\begin{array}{l}\text { Private } \\
\text { Hospital }\end{array}$ & $P$ Value \\
\hline Number of patients & 100 & 100 & \\
\hline \multicolumn{4}{|l|}{ Age (years) } \\
\hline Mean \pm SD & $34.3 \pm 14.7$ & $36.3 \pm 13.4$ & 0.3040 \\
\hline Range & 14-74 & $13-79$ & \\
\hline \multicolumn{4}{|l|}{ Gender } \\
\hline Male & 54 & 44 & 0.1572 \\
\hline Female & 46 & 56 & 0.1572 \\
\hline $\begin{array}{l}\text { Previous evaluation by other } \\
\text { physicians }\end{array}$ & 85 & 13 & $<0.0001$ \\
\hline Suggestive abdominal pain & 84 & 82 & 0.7066 \\
\hline Anorexia & 63 & 52 & 0.1532 \\
\hline Nausea and vomiting & 66 & 54 & 0.0833 \\
\hline Diarrhea & 19 & 8 & 0.0228 \\
\hline Temperature $>378^{\circ} \mathrm{C}$ & 41 & 15 & $<0,0001$ \\
\hline Pain on palpation & 96 & 98 & 0.4071 \\
\hline Rebound tenderness & 71 & 72 & 0.8755 \\
\hline Ultrasonography performed & 56 & 30 & 0.0002 \\
\hline
\end{tabular}


Table 2 - Patient operative and postoperative data by hospital

\begin{tabular}{|c|c|c|c|}
\hline Operative and Postoperative Data & Public Hospital & Private Hospital & $P$ Value \\
\hline Complicated appendicitis & 37 & 21 & 0.0127 \\
\hline \multicolumn{4}{|l|}{ Length of hospital stay (days) } \\
\hline Postoperative complications & 36 & 20 & 0.0117 \\
\hline Hospital readmission & 4 & 1 & 0.1742 \\
\hline Additional pathological findings & 2 & 1 & 0.5607 \\
\hline
\end{tabular}

Table 3 - Postoperative complications by hospital

\begin{tabular}{lccc}
\hline Complication & Public Hospital (n) & Private Hospital (n) & P Value \\
\hline Wound infection & 22 & 11 & 0.0361 \\
Pulmonary atelectasis & 3 & 4 & 0.7004 \\
Intrabdominal abscess & 3 & 1 & 0.3124 \\
Incisional hernia & 3 & 2 & 0.3124 \\
Urinary retention requiring catheterization & 3 & 0 & 0.6506 \\
Urinary infection & 1 & 1 & 0.3161 \\
Thrombophlebitis & 1 & & 1.0000 \\
\hline
\end{tabular}

manifestations were similar in both groups, except for diarrhea and temperature above $37.8^{\circ} \mathrm{C}$ that were more common in the public hospital group. Abdominal ultrasonography was performed more often in patients who underwent appendectomy at the public hospital $(n=56)$ than at the private hospital $(n=30)$ $(p=0.0002)$. This imaging exam was performed prior to hospital evaluation at request of the referral physician in 35 of the 56 patients of the public hospital and in 5 of the 30 patients of the private hospital.

Table 2 shows operative and postoperative data of patients at both hospitals. Time interval between onset of clinical manifestations and appendectomy was longer for the public hospital ( $3.0 \pm 1.8$ days) than for the private hospital ( $1.5 \pm 0.7$ days) $(p<0.0001)$. Appendectomy was performed by laparoscopic access more frequently at the private hospital (86 patients) than at the public hospital (22 patients) $(p<0.0001)$. Complicated appendicitis was more common at the public hospital $(n=37)$ than at the private hospital $(n=21)(p=0.0127)$.
Length of hospital stay was longer at the public hospital $(3.5 \pm 2.8$ days) than at the private hospital $(2.5 \pm 1.7$ days $)$ $(p=0.0024)$. Postoperative complications were more frequent at the public hospital $(n=36)$ than at the private hospital $(n=20)$ $(p=0.0117)$. Table 3 shows postoperative complications of patients of both hospitals. There were no deaths in either hospital. The most common complication in both hospitals was wound infection observed more commonly in patients submitted to open appendectomy. Percutaneous drainage was effective for all patients with intrabdominal abscesses, except for one at the public hospital requiring surgical drainage. Hospital readmission to evaluate and treat complications occurred in four patients of the public hospital and one of the private hospital. In addition to appendicitis, two patients at the public hospital and one at the private hospital upon examination had other pathological findings (carcinoid tumor of $<1 \mathrm{~cm}$ of diameter).. Time to resume routine activities (work and or study) was longer for the public hospital (33.2 \pm 8.3 days) than for the private hospital $(16.4 \pm 5.2$ days $)(p<0.0001)$. 
Multivariate logistic-regression analysis showed that the estimated probability of complicated appendicitis increased with the time interval between symptoms onset and appendectomy $(p<0.001)$. The estimated probability of complicated appendicitis increased from $1.8 \%$ in 2 days to $60 \%$ in 3 days, and to above $80 \%$ in 4 days. Kaplan-Meier analysis showed that the relationship between the cumulative probability of noncomplicated appendicitis and the time interval between onset of symptoms and appendectomy was different in the two hospitals $(p<0.001)$. In the private hospital, the cumulative probability decreased to $80 \%$ in 2 days and to less than $10 \%$ in 3 days. In the public hospital, the probability reduced to $80 \%$ in 4 days and to less than $10 \%$ in 6 days. Independent risk factor associated with complicated appendicitis was the time interval between onset of symptoms and appendectomy (odds ratio $=41.65,95 \% \mathrm{Cl}$ $\{$ confidence interval $\}=2.90-597.49, p<0.0001$ at the public hospital. Complicated appendicitis was associated with postoperative complications. There was no independent risk factor associated with complicated appendicitis in the private hospital.

\section{Discussion}

Some reports have disclosed important differences in medical evaluation and complication rate of patients submitted to appendectomy for acute appendicitis, related to type of hospital assistance, physician's specialty, geographic area, and patient's socioeconomic status ${ }^{17,20-22}$. In our study, we also observed important differences between a public hospital and a private hospital in the diagnosis and outcomes of patients with appendicitis who underwent appendectomy. More patients were previously evaluated by other physicians in the group from the public hospital than from the private hospital. Another striking difference was related to preoperative ultrasonography. This imaging exam was performed more often in patients from the public hospital. The main reason for this difference is that most patients seen at public hospital had ultrasonography performed at request of the referral physician prior to hospital evaluation. The influence of different surgical teams in the evaluation and treatment of patients with acute appendicitis was ruled out in our study since the surgical coordination and staff of both hospitals comprised the same group of surgeons.

Unnecessary imaging exams do not increase diagnosis accuracy, may delay appendectomy and may increase appendiceal perforation and postoperative complication rates ${ }^{3}$. Zilbert et al. performed a retrospective review of patients with confirmed appendicitis at a public city hospital and private university hospital in New York and compared management and outcomes $^{19}$. The length of stay was longer and more expensive imaging preoperative exams were performed in the public hospital than in the private hospital. In a survey with participation of almost all Netherland hospitals, it was reported that most patients suspected of having acute appendicitis were not submitted to pre-operative ultrasonography and or tomography ${ }^{23}$.

In our study, time interval between clinical manifestations onset and appendectomy was longer at the public hospital. This may be the main reason for the increase in rate of complicated appendicitis, in length of hospital stay and in postoperative complication, including fever and wound infection, observed at the public hospital. The most important factor that increases morbidity and mortality of acute appendicitis is delay in the diagnosis and treatment of this condition ${ }^{3}$. Immediate appendectomy has long been the recommended treatment of appendicitis because of the known risk of progression to perforation ${ }^{3,4}$. Rate of appendiceal perforation increases from less than $2 \%$ when appendectomy is performed within 36 hours of symptom onset to $5 \%$ after this time period ${ }^{3}$. Appendiceal perforation increases 10 times the rate of postoperative complications ${ }^{2,5,6}$.

Wound infection remains the most common reported complication after appendectomy and its incidence varies depending on the stage of appendicitis, patient age and physiologic condition, and whether the appendectomy is laparoscopic or open. Our rate of wound infection of $11 \%$ and $22 \%$ observed at the private hospital and at the public hospital respectively is similar to that reported in literature. In a meta-analysis of all randomized controlled trials published between 1995 and 2006, Bennett et al. $^{24}$ reported that the incidence of wound infection after laparoscopic appendectomy ranged from 0 to $18.5 \%$, with a mean of $4 \%$ and it was approximately half of that after open appendectomy. The incidence of wound infection in patients who underwent laparoscopic surgery is mainly due to wound contamination during removal of the appendix through the trocar or perforation of the retrieval bag.

Pulmonary atelectasis is the most common postoperative complication following thoracic and abdominal surgical procedures, but diagnosis is not established in the majority of cases because patients are asymptomatic and the disease is self-limited in most cases. ${ }^{25}$ When patients undergo routine chest radiography after laparoscopic procedures, the rate of pulmonary atelectasis may be as high as 30\%. ${ }^{25,26}$ Its incidence is less frequent after laparoscopic than open surgeries. ${ }^{25,26}$ In our study, we observed no difference between the two groups, possibly because we did not perform diagnostic exams routinely. In addition, other factors that are important in the pathogenesis of postoperative pulmonary atelectasis were not evaluated, such as duration of anesthesia, obesity, previous pulmonary disease, use of analgesics, and postoperative physiotherapy.

Differences between the two hospitals in our study are possibly due to the Brazilian health care system. There are basically three types of medical care coverage in Brazil: public (government), private insurance, and private patient. In the government medical care, patient is usually first evaluated in an outpatient clinic by a general physician and referred to a hospital when the diagnosis of appendicitis is established or suspected, which may delay appendectomy. Private patient or one with private health insurance is generally seen by a physician of his choice, usually a specialist, who makes the clinical evaluation and performs appendectomy in a shorter period of time. Further , time interval to perform preoperative exams, especially ultrasonography, is longer in the government medical care than in the private.

Increase in appendiceal perforation rate due to delay to emergency operative access has also been reported in other countries $^{18}$. In a comparative study between all patients diagnosed with acute appendicitis from 2001 to 2005 in Canada and the United States, Krajewski et al. demonstrated that odds of appendiceal perforation were significantly higher in the lowest income quartile than in the highest income bracket in the United 
States, however not in Canada ${ }^{18}$. The authors suggested that this finding is due to different access to emergency operative care in these two countries. In the United States, where 47 million Americans are uninsured, access to emergency care is related to socioeconomic status ${ }^{18}$. United States hospitals are concerned with patients' ability to pay medical bills ${ }^{18}$. In Canada, all citizens have universal health insurance and all patients have free access to emergency care, independent of the socioeconomic status.

Based on data from the National Hospital Ambulatory Medical Care Survey of the United States from 1997 to 2006, Wu et al. have also demonstrated that waiting time for consultation in the emergency department for evaluation of patients with acute appendicitis was related to their socioeconomic status ${ }^{27}$. It was higher for non-insured Hispanic patients than for other ethnic groups with insurance. Bickell et al. have also reported that emergency department length of stay and time for surgeons to establish diagnosis of acute appendicitis in New York were longer for non-white patients without private insurance ${ }^{28}$.

In our series, laparoscopic appendectomy was performed more frequently at the private hospital than at the public hospital. This was due to limited availability of a laparoscopic instrument in the public hospital, especially when surgery was performed at night. This is also observed in other countries. In all hospitals of the Province of Québec, Canada, the rate of appendectomy performed by laparoscopy was significantly lower in university hospitals than in non-teaching hospitals ${ }^{29}$. In a nationwide survey for appendectomies performed in the United States between 1997 and 2003, Van Hove et al. showed that the rate of laparoscopic appendectomy was related to the socioeconomic status of patients ${ }^{30}$. It was lower for non-white as well as lowincome patients .

Time to resume routine activities was longer for the public hospital, possibly due to two main reasons. First, complicated appendicitis, i.e. gangrene, perforation, abscess, or peritonitis, were more frequent in this hospital. Complicated appendicitis increases postoperative complication rate and hospital stay and consequently delays resuming routine activities ${ }^{12,31}$. Second, a greater number of patients underwent appendectomy by laparoscopy at the private hospital than at the public hospital. Laparoscopic appendectomy is associated with less delay in resuming routine activities and return to work when compared to open (conventional) appendectomy ${ }^{32-35}$.

Findings of this study may provide data to improve and optimize treatment of patients with acute appendicitis in public hospitals. Patients with clinical findings suggestive of acute appendicitis should not be submitted to routine time-consuming and expensive imaging studies, such as ultrasonography and computed tomography. These patients should undergo immediate appendectomy without further delay to reduce the rate of complicated appendicitis and postoperative morbidity.

\section{Conclusion}

This study concludes that there are important differences between a public hospital and a private hospital in the diagnosis and outcomes of patients with acute appendicitis submitted to appendectomy. More patients are previously evaluated by other physicians and are submitted to preoperative ultrasonography in the group from the public hospital than from the private hospital.
Time interval between onset of clinical manifestations and appendectomy, complicated appendicitis rate, length of hospital stay, postoperative complication rate and time to resume routine activities are higher for the public hospital.

Acknowledgments: The authors wish to thank Prof. PhD Mônica Nunes Lima for the statistical analyses.

\section{Conflict of interest: none}

\section{Resumo}

ApEndicectomia. estudo comparativo RETROSPECtivo entre UM HOSPITAL PÚBLICO E UM PRIVADO

Objetivo. Comparar dados dos pacientes submetidos à apendicectomia por apendicite aguda em um hospital público e um privado.

Métodos. O total de 200 prontuários médicos de pacientes que foram submetidos à apendicectomia por apendicite aguda em um hospital público $(n=100)$ e em um hospital privado $(n=100)$ foi revisado retrospectivamente.

Resultados. A idade média e a distribuição dos pacientes por sexo foram similares entre os dois hospitais. Um número maior de pacientes foi previamente avaliado por outro médico no grupo operado no hospital público $(n=85)$ do que no hospital privado $(n=13) \quad(p<0,0001)$. Ultrassonografia foi realizada mais frequentemente no hospital público $(n=56)$ do que no hospital privado $(n=30)$ ( $p=0,0002)$. O tempo de internação hospitalar foi mais longo no hospital público $(3,5 \pm 2,8$ dias) do que no hospital privado $(2,5 \pm 1,7$ dias) $(p=0,0024)$. Complicações pós-operatórias foram mais comuns no hospital público $(n=36)$ do que no hospital privado $(n=20)(p<0,0117)$. O tempo de retorno as atividades de rotina foi mais longo no hospital público (33.2 \pm 8.3 dias) do que no hospital privado (16.4 55.2 dias) $(p<0,0001)$. A análise de regressão logística mostrou que a probabilidade estimada da apendicite complicada aumenta com o intervalo de tempo entre o início dos sintomas e a apendicectomia $(p<0.001)$. O fator de risco independente associado com apendicite complicada foi o intervalo de tempo entre o início dos sintomas e a apendicectomia (odds ratio 41.65, 95\% Cl 2.90$597.49, p<0.0001)$ no hospital público. Não houve fatores de risco independente associados com apendicite complicada no hospital privado.

Conclusão. Existem importantes diferenças no processo diagnóstico e nos resultados dos pacientes submetidos à apendicectomia por apendicite aguda entre hospital público e privado. [Rev Assoc Med Bras 2010; 56(5): 522-7]

UnITERMos: Fatores socioeconômicos. Complicações pós-operatórias. Apendicite. Apendicectomia. Seguro saúde.

\section{REFERENCES}

1. Penfold RB, Chisolm DJ, Nwomeh BC, Kelleher KJ. Geographic disparities in the risk of perforated appendicitis among children in Ohio: 2001-2003. Int J Health Geogr. 2008;7:56-65.

2. Newman K, Ponsky T, Kittle K, Dyk L, Throop C, Gieseker K, Sills M, Gilbert J. Appendicitis 2000: variability in practice, outcomes, and resource utilization at thirty pediatric hospitals. J Pediatr Surg. 2003;38372-9.

3. Bickell NA, Aufses AH Jr, Rojas M, Bodian C. How time affects the risk of rupture in appendicitis. J Am Coll Surg. 2006.203:401-6. 
4. Wullstein C, Barkhausen S, Gross E. Results of laparoscopic vs. conventional appendectomy in complicated appendicitis. Dis Colon Rectum. 2001;44:1700-5

5. Papaziogas B, Tsiaousis P, Koutelidakis I, Giakoustidis A, Atmatzidis S, Atmatzidis K. Effect of time on risk of perforation in acute appendicitis. Acta Chir Belg. 2009;109:75-80

6. Kearney D, Cahill RA, OBrien E, Kirwan WO, Redmond HP. Influence of delays on perforation risk in adults with acute appendicitis. Dis Colon Rectum. 2008;51:1823-7.

7. Carvalho BR, Diogo-Filho A, Fernandes C, Barra CB. Leucograma, proteína $C$ reativa, alfa-1 glicoproteína ácida e velocidade de hemossedimentação na apendicite aguda. Arq Gastroenterol. 2003;40:25-30.

8. Costa JIF, Coelho Filho JM, Lima JMC, Mota RMS, Sousa Filho VJ. Valor da ultra-sonografia abdominal com transdutor multifreqüencial de 5 a $10 \mathrm{mhz}$ no diagnóstico de apendicite. Radiol Bras. 2002;35:85-8.

9. Vital Jr PF, Martins JL. Estado atual do diagnóstico e tratamento da apendicite aguda na criança: avaliação de 300 casos. Rev Col Bras Cir. 2005;32:310-5.

10. Zorzetto AA, Urban LABD, Liu CB, Cruz OR, Vitola MLM, Awamura Y, et al. 0 uso da ultra-sonografia no diagnóstico e evolução da apendicite aguda. Radiol Bras. 2003;36:71-5.

11. Gomes CA, Nunes TA. Classificação laparoscópica da apendicite aguda: correlação entre graus da doença e as variáveis perioperatórias. Rev Col Bras Cir. 2006;33:289-93.

12. Silva SM, Almeida SB, Lima OAT, Guimarães GMN, Silva ACC, Soares AF. Fatores de risco para as complicações após apendicectomias em adultos. Rev Bras Colo-Proctol. 2007:27:31-6.

13. Brenner AS, Santin J, Virmond Neto F, Boursheid T, Valarini R, Rydygier R. Apendicectomia em pacientes com idade superior a 40 anos: análise dos resultados de 217 casos. Rev Bras Colo-Proctol. 2006;26:128-32.

14. Almeida MWR, João AT, Oliveira FS, Mattos HC, Silva AR, Silva MGB. Influência da idade no tempo de internação e no grau evolutivo das apendicites agudas Rev Col Bras Cir. 2006;33:294-7.

15. Lima GJS, Silva AL, Castro EG, Abras GM, Pires LJS, Leite RFG. Efetividade e segurança da apendicectomia videoassistida em porta única transumbilical em adolescentes e adultos. Rev Col Bras Cir. 2008;35:244-51

16. Fischer CA, Pinho MSL, Ferreira S, Milani CAC, van Santen CR, Marquardt RA. Apendicite aguda: existe relação entre o grau evolutivo, idade e o tempo de internação? Rev Col Bras Cir. 2005;32:136-8.

17. Whisker L, Luke D, Hendrickse C, Bowley DM, Lander A. Appendicitis in children: a comparative study between a specialist paediatric centre and a district general hospital. J Pediatr Surg. 2009;44:362-7.

18. Krajewski SA, Hameed SM, Smink DS, Rogers SO Jr. Access to emergency operative care: a comparative study between the Canadian and American health care systems. Surgery. 2009;146:300-7.

19. Zilbert NR, Stamell EF, Ezon I, Schlager A, Ginsburg HB, Nadler EP. Management and outcomes for children with acute appendicitis differ by hospital type: areas for improvement at public hospitals. Clin Pediatr (Phila). 2009;48:499-504.

20. Kharbanda AB, Fishman SJ, Bachur RG. Comparison of pediatric emergency physicians' and surgeons' evaluation and diagnosis of appendicitis. Acad Emerg Med. 2008;15:119-25.
21. Alexander F, Magnuson D, DiFiore J, Jirousek K, Secic M. Specialty versus generalist care of children with appendicitis: an outcome comparison. J Pediatr Surg. 2001;36:1510-3.

22. Kokoska ER, Minkes RK, Silen ML, Langer JC, Tracy TF, Snyder CL, Dillon PA, Weber TR. Effect of pediatric surgical practice on the treatment of children with appendicitis. Pediatrics. 2001;107:1298-301.

23. Cobben LP, Bakker OJ, Puylaert JB, Kingma LM, Blickman JG. Imaging of patients with clinically suspected appendicitis in the Netherlands: conclusions of a survey. Br J Radiol. 2009;82:482-5.

24. Bennett J, Boddy A, Rhodes M. Choice of approach for appendectomy: a metaanalysis of open versus laparoscopic appendicectomy. Surg Laparosc Endosc Percutan Tech. 2007; 17:245-55.

25. Hasukić S, Mesić D, Dizdarević E, Keser D, Hadziselimović S, Bazardzanović M. Pulmonary function after laparoscopic and open cholecystectomy. Surg Endosc. 2002;16:163-5

26. Ravimohan SM, Kaman L, Jindal R, Singh R, Jindal SK. Postoperative pulmonary function in laparoscopic versus open cholecystectomy: prospective, comparative study. Indian J Gastroenterol. 2005;24:6-8.

27. Wu BU, Banks PA, Conwell DL. Disparities in emergency department wait times for acute gastrointestinal illnesses: results from the National Hospital Ambulatory Medical Care Survey, 1997-2006. Am J Gastroenterol. 2009;104:1668-73.

28. Bickell NA, Hwang U, Anderson RM, Rojas M, Barsky CL. What affects time to care in emergency room appendicitis patients? Med Care. 2008;46:417-22.

29. Gagné JP, Billard M, Gagnon R, Laurion M, Jacques A. Province-wide population survey of acute appendicitis in Canada. New twists to an old disease. Surg Endosc. 2007;21:1383-7.

30. Van Hove C, Hardiman K, Diggs B, Deveney C, Sheppard B. Demographic and socioeconomic trends in the use of laparoscopic appendectomy from 1997 to 2003. Am J Surg. 2008;195:580-3.

31. Ekeh AP, Monson B, Wozniak CJ, Armstrong M, McCarthy MC. Management of acute appendicitis by an acute care surgery service: is operative intervention timely? J Am Coll Surg. 2008;207:43-8.

32. Ming PC, Yan TY, Tat LH. Risk factors of postoperative infections in adults with complicated appendicitis. Surg Laparosc Endosc Percutan Tech. 2009; 19:244-8

33. Malik AM, Talpur AH, Laghari AA. Video-assisted laparoscopic extracorporeal appendectomy versus open appendectomy. J Laparoendosc Adv Surg Tech A. 2009;19:355-9.

34. Kirshtein B, Perry ZH, Mizrahi S, Lantsberg L. Value of laparoscopic appendectomy in the elderly patient. World J Surg. 2009;33:918-22.

35. Hussain A, Mahmood H, Nicholls J, El-Hasani S. Prevention of intra-abdominal abscess following laparoscopic appendicectomy for perforated appendicitis: a prospective study. Int J Surg. 2008;6:374-7.

Artigo recebido: 07/09/09

Aceito para publicação: 24/05/10 